\title{
Short-term effects of thinning, clear-cutting and stump harvesting on methane exchange in a boreal forest
}

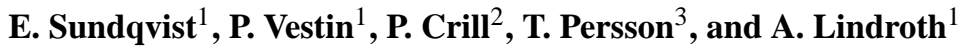 \\ ${ }^{1}$ Department of Physical Geography and Ecosystem Science, Lund University, Lund, Sweden \\ ${ }^{2}$ Department of Geological Sciences, Stockholm University, Stockhol, Sweden \\ ${ }^{3}$ Department of Ecology, Swedish University of Agricultural Sciences, Uppsala, Sweden \\ Correspondence to: E. Sundqvist (elin.sundqvist@nateko.lu.se)
}

Received: 25 February 2014 - Published in Biogeosciences Discuss.: 24 March 2014

Revised: 1 October 2014 - Accepted: 7 October 2014 - Published: 12 November 2014

\begin{abstract}
Forest management practices can alter soil conditions, affecting the consumption and production processes that control soil methane $\left(\mathrm{CH}_{4}\right)$ exchange. We studied the short-term effects of thinning, clear-cutting and stump harvesting on the $\mathrm{CH}_{4}$ exchange between soil and atmosphere at a boreal forest site in central Sweden, using an undisturbed plot as the control. Chambers in combination with a highprecision laser gas analyser were used for continuous measurements. Both the undisturbed plot and the thinned plot were net sinks of $\mathrm{CH}_{4}$, whereas the clear-cut plot and the stump harvested plot were net $\mathrm{CH}_{4}$ sources. The $\mathrm{CH}_{4}$ uptake at the thinned plot was reduced in comparison to the undisturbed plot. The shift from sink to source at the clear-cut and stump harvested plots was probably due to a rise in the water table and an increase in soil moisture, leading to lower gas diffusivity and more reduced conditions, which favour $\mathrm{CH}_{4}$ production by archea. Reduced evapotranspiration after harvesting leads to wetter soils, decreased $\mathrm{CH}_{4}$ consumption and increased $\mathrm{CH}_{4}$ production, and should be accounted for in the $\mathrm{CH}_{4}$ budget of managed forests.
\end{abstract}

\section{Introduction}

Methane $\left(\mathrm{CH}_{4}\right)$ is the second most important carbon greenhouse gas, with a radiative forcing at least 25 times higher than carbon dioxide from a 100-year perspective (Shindell, et al., 2009). Consumption of $\mathrm{CH}_{4}$ by methanotrophic bacteria in the aerobic part of the soil profile (Harriss et al., 1982) and production of $\mathrm{CH}_{4}$ by archaeans in the anaerobic water-saturated part of the profile (Ehhalt, 1974) and at anaerobic micro-sites (von Fischer and Hedin, 2002; Kammann et al., 2009) often occur simultaneously (Le Mer and Roger, 2001; Megonigal and Guenther, 2008). Generally, well-aerated forest soils are net sinks of atmospheric $\mathrm{CH} 4$ (Van Amstel, 2012). Consumption in soils is the second largest sink of $\mathrm{CH}_{4}$ after tropospheric oxidation by hydroxyl radicals with a global sink capacity estimated recently at 28-32 $\mathrm{Tg} \mathrm{CH}_{4} \mathrm{yr}^{-1}$ (Kirschke et al., 2013). The soil sink capacity is higher in forest soils than in grasslands and arable land (Dutaur and Verchot, 2007), and therefore the global $\mathrm{CH}_{4}$ budget is sensitive to disturbances in forests. Conversion of natural forests to arable land, increased $\mathrm{N}$ deposition from the atmosphere and $\mathrm{N}$ fertilization of agricultural lands are estimated to have reduced the global $\mathrm{CH}_{4}$ soil sink by about $30 \%$ between 1880 and 1980 (Ojima et al., 1993).

Disturbances, including forest management practices, can also have an impact on the soil $\mathrm{CH}_{4}$ exchange by altering soil conditions, such as soil moisture (Zerva and Menucuccini, 2005; Castro et al., 2000), water table depth (Zerva and Menucuccini, 2005), bulk density (Mojeremane et al., 2012), soil temperature (Zerva and Menucuccini, 2005; Thibodeau et al., 2000), nutrient content (Smolander et al., 1998) and $\mathrm{pH}$ (Smolander et al., 1998). $\mathrm{CH}_{4}$ oxidation in soil has been observed to be controlled by diffusivity (Koschorreck and Conrad, 1993; Whalen and Reeburgh, 1996; Gulledge and Schimel, 1998). A well-drained coarse soil facilitates the exchange of oxygen and $\mathrm{CH}_{4}$ between the atmosphere and the deeper soil levels, where $\mathrm{CH}_{4}$ is consumed (Verchot et al., 2000). By contrast, increased soil moisture and soil compaction reduce the diffusivity and promote anoxic environments in which $\mathrm{CH}_{4}$ can be produced (Koschorreck and 
Conrad, 1993; Whalen and Reeburgh, 1996; Gulledge and Schimel, 1998). Changes in water table depth also influence the $\mathrm{CH}_{4}$ exchange by altering the relative extent of anaerobic and aerobic zones in the soil (Whalen and Reeburgh, 1990). Temperature is also an important driver of $\mathrm{CH}_{4}$ production, with higher temperatures leading to higher $\mathrm{CH}_{4}$ production, while consumption by methanotrophs is not as strongly enhanced (Dunfield et al., 1993). Increased nitrogen content in the soil has been shown to inhibit $\mathrm{CH}_{4}$ consumption in several studies (Steudler et al., 1989; Hutsch et al., 1993; Wang and Ineson, 2003). This is due to competition by certain nitrifiers, which might occupy the same niche in the soil. These nitrifiers have an enzyme similar to methanotrophs and are also able to oxidize $\mathrm{CH}_{4}$, though possibly at a lower rate (Hutsch et al., 1993).

Summarizing the effects of forest management practices on $\mathrm{CH}_{4}$ exchange is difficult, since relatively few studies have been made on this topic, and they have covered a range of management practices, soil types and forests. However, several studies reported that clear-cutting led to reduced $\mathrm{CH}_{4}$ uptake, possibly due to increased soil moisture (Wu et al., 2011), increased nitrogen availability (Steudler et al., 1991; Bradford et al., 2000), changes in pH (Bradford et al., 2000) and erosion (Kagotani et al., 2001). A shift from soil $\mathrm{CH}_{4}$ sink to soil $\mathrm{CH}_{4}$ source has been reported due to a rise in water table depth combined with increases in substrate availability (Zerva and Mencuccini, 2005) and due to increases in soil moisture (Castro et al., 2000). The same shift from sink towards emission has been seen following soil compaction by skid trails and machinery, as a part of clear-cutting (Teepe et al., 2004) and thinning (Keller et al., 2005). One study on a clear-cut drained peat soil showed no substantial changes in $\mathrm{CH}_{4}$ exchange (Huttunen et al., 2003).

Site preparation by mounding at clear cuts can have a negative impact on $\mathrm{CH}_{4}$ exchange from a climate perspective. In one study, compaction of the soil by excavators during mounding increased $\mathrm{CH}_{4}$ emissions (Mojeremane et al., 2012). $\mathrm{CH}_{4}$ emissions from stagnant water in hollows created during mounding can sometimes exceed the consumption in the mineral soil on top of the mounds (Mojeremane et al., 2010). However, bedding after clear-cutting has resulted in reduced $\mathrm{CH}_{4}$ emissions (Castro et al., 2000). Drainage can also reduce $\mathrm{CH}_{4}$ emissions following clear-cutting, but its positive effect on $\mathrm{CH}_{4}$ emissions was outweighed by increases in $\mathrm{CO}_{2}$ emissions when drainage was conducted on saturated peaty soils (Mojeremane et al., 2012).

Stump harvesting for bioenergy production has recently been proposed as a way of substituting fossil fuel $\mathrm{CO}_{2}$ emissions in Sweden. To our knowledge, there are no publications on the effects of stump harvesting on $\mathrm{CH}_{4}$ exchange, although it is likely to have a similar effect to other clearcutting and site preparation actions. There are a few studies on the effect of thinning on $\mathrm{CH}_{4}$ exchange in a forest. Reduced $\mathrm{CH}_{4}$ uptake due to increased nitrogen availability has been reported (Thibodeau et al., 2000). A study at three thinned plots in a temperate beech forest reported slightly reduced emissions at one plot, whereas the other two were not significantly different from the control plots (Dannenmann et al., 2007). Another study in a temperate forest actually showed an increased $\mathrm{CH}_{4}$ uptake after thinning, as opposed to a decrease at two adjacent clear-cut areas (Bradford et al., 2000). Some studies found no significant changes in $\mathrm{CH}_{4}$ exchange after thinning (Wu et al., 2011; Sullivan et al., 2008).

The objective of this study was to quantify the short-term $\mathrm{CH}_{4}$ exchange at four sites: an undisturbed forest plot, a thinned forest plot, a clear-cut plot with stumps remaining and a clear-cut plot with stumps removed. The comparison between the different treatments is facilitated because all four sites are within a defined area and have a common soil type. We also wanted to investigate how soil moisture, soil temperature and water table depths influenced the soil $\mathrm{CH}_{4}$ exchange.

\section{Methods}

\subsection{Site description}

The $\mathrm{CH}_{4}$ exchange measurements took place in a forested area on the southern edge of the boreal zoon, at Norunda research station in central Sweden $\left(60^{\circ} 05^{\prime} \mathrm{N}, 17^{\circ} 29^{\prime} \mathrm{E}\right)$. Hourly automated chamber measurements were made using a system that was moved between four differently managed plots (Fig. 1). One plot contained undisturbed 120-year-old mixed pine (Pinus sylvestris) and spruce (Picea abies) forest, which had not been thinned or fertilized in several decades. The other three plots were recently (2008-2010) impacted by either thinning, clear-cutting or stump harvesting. Thinning was done in order to simulate continuous cover forestry, rather than to increase growth.

Measurements were made using four chambers at the thinned plot, and five chambers at each of the other plots. The chamber locations were named $U_{1}-U_{5}$ at the undisturbed plot, $T_{1}-T_{4}$ at the thinned plot, $C_{1}-C_{5}$ at the clear-cut plot and $S_{1}-S_{5}$ at the stump harvested plot. At the clear-cut and stump harvested plots, half of the chamber frames were positioned on bare soil, where organic and mineral soil layers were mixed. The disturbance was caused either by stump harvesting or by site preparation to facilitate the establishment and growth of new plants. The remaining frames were placed on soil surfaces with intact vegetation. The clear-cut and stump harvested plots had been fertilized in 1976, 1988 and 1998.

Ground vegetation was sparse and dominated by bilberry (Vaccinium myrtillus) and feather mosses (Hylocomium splendens and Pleurozium schreberi). There were more shrubs and grass at the clear-cut site, following the soil's disturbance. The soil was a glacial till (Lundin et al., 1999) with an organic layer of $3-10 \mathrm{~cm}$ depth. For the period $1980-2010$, the mean air temperature was $6.5^{\circ} \mathrm{C}$, and 


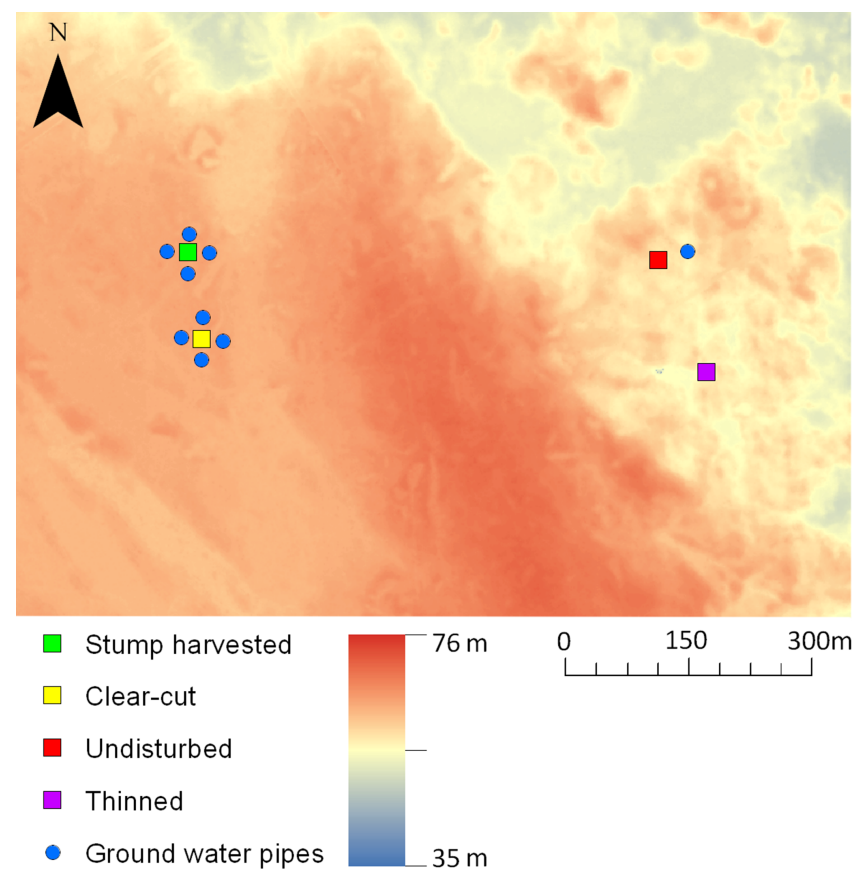

Figure 1. Schematic picture of the different plots and some of the groundwater pipes. Three more pipes are located within the clearcut and at the stump harvested plots, but are covered by the plot symbol. The background consists of a digital elevation model showing the height above sea level for each square metre (Digital elevation model (DEM) data kindly provided by N. Kljun et al.).

the mean annual precipitation was $576 \mathrm{~mm}$ (measured $30 \mathrm{~km}$ south of Norunda).

\subsection{Timing of measurements}

Thinning took place in November 2008, the clear-cutting in February 2009 and stump harvesting in May 2010. Both the clear-cut plot and the stump harvested plot were mounded and planted in May 2010. The chamber frames were installed in 2005 at the undisturbed and thinned plots, and in June 2010 at the clear-cut and stump harvested plots, to allow time for soil and vegetation to recover from the disturbance.

Due to equipment limitations, measurements were conducted at one plot at a time. Measurements at the thinned plot were made from 1 August 2009 to 31 May 2010, at the undisturbed plot from 7 July 2010 to 4 October 2010, at the stump harvested plot from 7 October 2010 to 20 October 2010 and at the clear-cut plot from 21 October to 9 November 2010. Winter data at the thinned plot from 1 December 2009 to 14 April 2010 were not used in the analyses due to uncertainties in the measurements caused by snow and frost.

\subsection{Equipment}

We used automated, transparent chambers of Polymethyl methacrylate in combination with a high-precision off-axis integrated cavity output spectroscopy (ICOS) laser gas analyser - DLT-100; Los Gatos Research (LGR) - for simultaneous concentration measurements of $\mathrm{CH}_{4}, \mathrm{CO}_{2}$ and $\mathrm{H}_{2} \mathrm{O}$. The chambers had a volume of 110 litres and covered a surface area of $0.2 \mathrm{~m}^{2}$. Gas concentrations in the chambers were measured after closure by recirculating the air through the gas analyser for $6 \mathrm{~min}$. The flow rate between chambers and manifolds was $8-10 \mathrm{~L} \mathrm{~min}^{-1}$. This air stream was subsampled and passed through the analyser at a flow rate of 1.2 $\mathrm{L} \mathrm{min}^{-1}$. A fan was installed in each chamber, designed to ensure sufficient mixing of chamber headspace air without disturbing the laminar boundary layer on the ground. Soil moisture was measured in the chambers at a $0-5 \mathrm{~cm}$ depth with a Ml-2× ThetaProbe from Delta-T Devices. The soil temperature was measured at a $5 \mathrm{~cm}$ depth inside the chambers using a type $\mathrm{T}$ thermocouple. Soil temperature measurements at the thinned plot did not work properly and so temperature data from the undisturbed plot, $125 \mathrm{~m}$ away, were used instead.

\subsection{Water table}

There were differences in height between the chamber frames relative to the groundwater table. One pipe with continuous measurements of the groundwater table was located $125 \mathrm{~m}$ from the thinned plot and $30 \mathrm{~m}$ from the undisturbed plot (Fig. 1). The groundwater table at these plots was treated as horizontal. At the clear-cut and stump harvested plots, the groundwater table was measured manually in seven pipes at each plot, on the 8 and 20 October 2010 and 2 November 2010. Some of these pipes are shown in Fig. 1. An inverse distance-weighting model was used to calculate the height of the groundwater table in relation to the ground surface for $40 \mathrm{~m}^{2}$ areas surrounding the chamber frames. The groundwater table was also measured continuously at one position on the clear-cut plot.

\subsection{Soil sampling}

Soil samples were taken in order to determine organic carbon $(\mathrm{C})$ and nitrogen $(\mathrm{N})$ content and $\mathrm{pH}$ in the top $20 \mathrm{~cm}$ of the soil, including the humus layer, where the chambers had been positioned. The litter layer was not taken into account. Sampling was done in November 2010 at the clear-cut and stump harvested plots and in September 2012 at the undisturbed and thinned plots.

At the clear-cut and stump harvested plots, humus layer samples were taken, at the border between organic and mineral soil layers, using a $10 \mathrm{~cm} \times 10 \mathrm{~cm}$ quadratic frame. The mineral soil was sampled with a $15.9 \mathrm{~cm}^{2}$ steel corer to a depth of $20 \mathrm{~cm}$, but it was subdivided in the field into $0-10$ 
and $10-20 \mathrm{~cm}$ layers. Humus samples were treated individually, while the mineral soil samples were pooled plot-wise for each soil layer. The samples, folded in plastic bags, were transported in cooling boxes to the laboratory, where they were kept fresh at $4-5{ }^{\circ} \mathrm{C}$ during the preparation process before the final analyses.

Soil samples were passed through either a $5 \mathrm{~mm}$ (humus samples) or a $2 \mathrm{~mm}$ (mineral soil) mesh. Stones and gravel $>2 \mathrm{~mm}$ diameter not passing the mesh were always rejected, as were any roots. The sieved soil material from each sample was carefully mixed and divided into a number of subsamples for determination of soil $\mathrm{pH}\left(\mathrm{H}_{2} \mathrm{O}\right)$ and total $\mathrm{C}$ and $\mathrm{N}$ content. Fresh weight : dry weight ratios were determined after drying the sub-samples at $105^{\circ} \mathrm{C}$ for $24 \mathrm{~h}$. Soil layer $\mathrm{pH}$ was determined with a glass electrode in the supernatant after shaking for $2 \mathrm{~h}$ on a rotary shaker, and sedimentation in an open flask for another $22 \mathrm{~h}$. The proportion of fresh soil to distilled water was $1: 1$ by volume, compared to about $1: 10$ for dry matter: water for humus, and $1: 2.5$ for mineral soil. Total $\mathrm{C}$ and $\mathrm{N}$ content was determined, using vacuum-dried soil samples at $60^{\circ} \mathrm{C}$ for $24 \mathrm{~h}$ in a Carlo Erba NA 1500 analyser. Because soil pH was always below 6, we assumed that there was no carbonate $\mathrm{C}$, and all $\mathrm{C}$ analysed was assumed to be organic $\mathrm{C}$.

At the undisturbed and thinned plots, a cylindrical metal corer with an $11 \mathrm{~cm}^{2}$ opening was pressed horizontally into the humus layer, and also at a $5 \mathrm{~cm}$ and $10 \mathrm{~cm}$ depth in the mineral layer. At some of the measurement locations (T1, T4, U2, U6), large stones, rocks and roots occupied a large volume of the mineral soil, so that sampling at a $10 \mathrm{~cm}$ depth in the mineral soil was not possible. The soil samples were kept below $5{ }^{\circ} \mathrm{C}$ until they were analysed.

The total amount of $\mathrm{C}$ and $\mathrm{N}$ in the soil samples at the undisturbed and thinned plots was analysed with an element analyser (Elementar Analysensysteme GmbH, Germany). The $\mathrm{pH}$ value was measured after $2 \mathrm{~h}$ equilibration with a $0.1 \mathrm{M}$ barium chloride solution (Orion Research model Microprocessor Ionanalyzer/901). The extractions were made on fresh material. Before determining the bulk density, the samples were oven dried for $48 \mathrm{~h}$ at $100^{\circ} \mathrm{C}$ and then sieved through a $2 \mathrm{~mm}$ mesh.

\subsection{Data analyses}

The rate of change of $\mathrm{CH}_{4}$ concentration $\left(\mathrm{dC}_{\mathrm{CH}_{4}} / \mathrm{d} t\right)$ within the chamber was calculated using a linear fit to the first $2 \mathrm{~min}$ of concentration data measured by the gas analyser, beginning immediately after chamber closure. We calculated the $r^{2}$ values for the fits of five different slopes, which were lagged at $10 \mathrm{~s}$ intervals after chamber closure. The fit with the highest $r^{2}$ value was then selected. The $\mathrm{CH}_{4}$ flux $\left(J_{\mathrm{CH}_{4} \text { flux }}\right)$ was calculated as $J_{\mathrm{CH}_{4} \text { flux }}=\frac{\mathrm{d} C}{\mathrm{~d} t} \frac{V}{A}$, where $C$ is the molar density $\left(\mu \mathrm{mol} \mathrm{m}{ }^{-3}\right), V\left(\mathrm{~m}^{3}\right)$ is the chamber volume and $A\left(\mathrm{~m}^{2}\right)$ is ground surface area. Fluxes with an $r^{2}$ value higher than 0.3 were generally kept for further analyses. An $r^{2}$ of 0.3 was the limit when the fluxes were significantly different from 0 . A few outliers that passed the $r^{2}$ limit were visually sorted out based on normalized root mean square error. Data kept for further analyses corresponded to $98 \%$ of the data at the undisturbed plot, $97 \%$ of the data at the thinned plot, $84 \%$ of the data at the clear-cut plot and $77 \%$ of the data at the stump harvested plot.

Minimum flux detection (MDF) limit was calculated as $\mathrm{MDF}=\frac{\sigma}{t}$, where $t$ is the measurement time for one specific measurement and $\sigma$ is the standard deviation for the concentration measurement. For a chamber the size as used in this study, the MDF for a single measurement was $2.8 \mu \mathrm{mol} \mathrm{m}{ }^{-2} \mathrm{~h}^{-1}$. For daily average values of hourly measurements, this value is reduced to $<1 \mu \mathrm{mol} \mathrm{m}{ }^{-2} \mathrm{~h}^{-1}$, since the MDF value should be divided by the square root of the number of measurements. It is important to note that, while fluxes below the MDF cannot be securely detected, they must still be considered. For example, consider time series where fluxes decrease smoothly from an emission peak to an uptake. In the transition phase from net emissions to net uptake, fluxes will be close to 0 . Removing fluxes $<\mathrm{MDF}$ could possibly bias the result towards a stronger sink or source than those for which times series from the individual chambers give support. Therefore, the fluxes within the MDF interval will also be kept in the analyses. Removing fluxes within the MDF interval for a single measurement $\left( \pm 2.8 \mu \mathrm{mol} \mathrm{m}{ }^{-2} \mathrm{~h}^{-1}\right)$ would lead to a decrease in the number of flux measurements by $0,16,13$ and $30 \%$ for the undisturbed, thinned, clear-cut and stump harvested plots, respectively, and not change the mean exchange of $\mathrm{CH}_{4}$ at any of the plots by more than $0.6 \mu \mathrm{mol} \mathrm{m}^{-2} \mathrm{~h}^{-1}$.

Correction of the measured $\mathrm{CH}_{4}$ concentrations for dilution by water vapour was only possible at the undisturbed, clear-cut and stump harvested plots after water vapour measurements started in June 2010. This means that daytime data (global radiation $>20 \mathrm{~W} \mathrm{~m}^{-2}$ ) from the thinned plot had to be excluded from the analyses. During the night, the dilution effect had very little impact.

The impact of the environmental variables (soil temperature, soil moisture, and water table depth) on $\mathrm{CH}_{4}$ exchange was analysed separately by Spearman linear correlations using the "corr" function, and by multiple linear regressions on standardized data using the "stepwisefit" function (both of which used Matlab, version R2009b). The stepwise regression analyses were performed by bi-directional elimination. $\mathrm{P}$ values were used in the selection process. The analysis was made on standardized data to adjust for the disparity in variable sizes, which makes the outcome of the analyses, the coefficients, comparable. The coefficients would be useful in the modelling of $\mathrm{CH}_{4}$ exchange. A variable with a larger coefficient has a higher impact on the $\mathrm{CH}_{4}$ exchange. Standardization for a data point $x_{i}$ was made by $x_{i}=\frac{x_{i}-\bar{x}}{\sigma}$, where $\bar{x}$ is the average of all data points and $\sigma$ is the standard deviation of all data. An $r^{2}$ value for the overall model was also calculated, showing how much of the variance in $\mathrm{CH}_{4}$ exchange is 


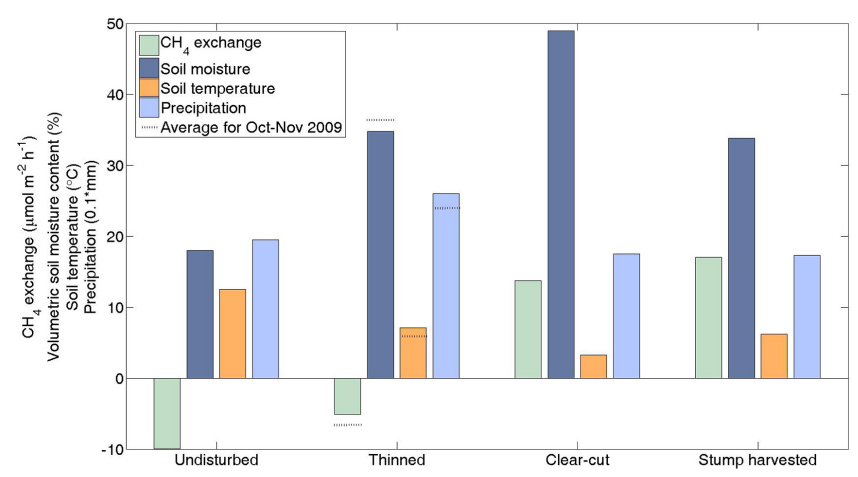

Figure 2. Average $\mathrm{CH}_{4}$ exchange rates, soil moisture and soil temperature at the four sampling plots. Data from the entire measurement period at each plot are included. The dashed line at the thinned plot represents average values for October and November, since measurements at the clear-cut and stump harvested plots were conducted during this part of the year.

not explained by the environmental variables included in the analyses.

The significance of mean values at the measurement locations was calculated with the $t$ test function (also Matlab, version R2009b).

\section{Results}

\subsection{Environmental conditions}

There were differences in soil moisture and soil temperatures among the plots. On average, the undisturbed forest plot, with measurements exclusively from the summer season (July through September) had the driest and warmest records, and the measurement locations were also further above the groundwater table than at other plots (Fig. 2, Table 1). The clear-cut plot, which was measured in October and November, showed the coldest and wettest conditions, including the highest water table. Four of the five measurement locations at this plot were, on average, less than $15 \mathrm{~cm}$ above the groundwater table (Fig. 2, Table 1). The thinned plot and the stump harvested plot had similar average moisture and temperature conditions, but the measurements at the thinned plot proceeded over a longer time period and thus the conditions varied more. The thinned plot also had a generally deeper groundwater table than the stump harvested plot (Fig. 2, Table 1).

Soil $\mathrm{N}$ and $\mathrm{C}$ content and $\mathrm{pH}$ were higher at the clearcut and stump harvested plots than at the undisturbed and thinned plots (Table 1).

\section{2 $\mathrm{CH}_{4}$ exchange}

The mean $\mathrm{CH}_{4}$ exchange of all measurement locations within the plots were as follows: the undisturbed plot and the thinned plot were net $\mathrm{CH}_{4}$ sinks of $-10 \mu \mathrm{mol} \mathrm{m}^{-2} \mathrm{~h}^{-1}$ and $-5 \mu \mathrm{mol} \mathrm{m}^{-2} \mathrm{~h}^{-1}$, respectively, while the clear-cut plot and the stump harvested plot were net sources of $13.6 \mu \mathrm{mol} \mathrm{m}^{-2} \mathrm{~h}^{-1}$ and $17 \mu \mathrm{mol} \mathrm{m}^{-2} \mathrm{~h}^{-1}$, respectively (Fig. 2). However, the $\mathrm{CH}_{4}$ exchange varied within the plots. At the clear-cut and stump harvested plots, both net sources and net sinks existed (Fig. 3). Plot $T_{3}$ and $T_{4}$ at the thinned plot shifted between net daily $\mathrm{CH}_{4}$ sinks and net daily $\mathrm{CH}_{4}$ sources on a few occasions (Fig. 3b). Fluxes ranged from -7.2 to $-11.6 \mu \mathrm{mol} \mathrm{m} \mathrm{m}^{-2} \mathrm{~h}^{-1}$ at the undisturbed plot, from -0.3 to $-8.6 \mu \mathrm{mol} \mathrm{m}^{-2} \mathrm{~h}^{-1}$ at the thinned plot, from -3.0 to $32.5 \mu \mathrm{mol} \mathrm{m}^{-2} \mathrm{~h}^{-1}$ at the clear-cut plot and from -2.9 to $74.0 \mu \mathrm{mol} \mathrm{m}^{-2} \mathrm{~h}^{-1}$ at the stump harvested plot (Fig. 3).

\subsection{Drivers of $\mathrm{CH}_{4}$ exchange at the undisturbed and thinned plots}

Linear regression analyses between $\mathrm{CH}_{4}$ exchange and climatic variables showed that, for most measurement locations at the undisturbed and thinned plots, consumption significantly $(p<0.001)$ increased with decreasing soil water content, decreasing water table depth and increasing temperatures. Exceptions to this were net $\mathrm{CH}_{4}$ uptake at locations $T_{3}$ and $T_{4}$, which decreased with increasing temperatures, and net $\mathrm{CH}_{4}$ uptake at locations $T_{2}$ and $T_{4}$, which decreased with decreasing soil moisture (Table 2). Figure 5 shows an example of the $\mathrm{CH}_{4}$ exchange response to temperature and soil water conditions at plot $U_{4}$.

Monthly multiple linear regression analyses (Table 3) added some temporal information to the $\mathrm{CH}_{4}$ exchange at the undisturbed and thinned plots. At the undisturbed plot, the water table depth affected $\mathrm{CH}_{4}$ consumption in August. In September 2010, temperature was the most influential variable at all measurement locations. In July 2010, the result was less distinct, showing some measurement locations with a higher dependency on water table depth, soil moisture and some measurement locations with a higher dependency on temperature. The clearest result at the thinned plot was a dependency on soil moisture at measurement locations $T_{1}$ and $T_{3}$ in August 2009 and at locations $T_{1}$ and $T_{2}$ in April 2010 (Table 3). Soils were wetter than average in August and April, due to heavy rains in June and July 2009, and snowmelt in spring 2010. However, according to the $r^{2}$ value of the overall model, there is a lot of unexplained variance in the $\mathrm{CH}_{4}$ exchange at all measurement locations.

\subsection{Drivers of $\mathrm{CH}_{4}$ exchange at the clear-cut and stump harvested plots}

Generally, at the clear-cut and stump harvested plots, the measurement locations with net emissions of $\mathrm{CH}_{4}$ had either a relatively short distance to water table or were disturbed by site preparation, or both, although there were exceptions. Plots $S_{4}$ and $S_{5}$ had the same water table depth and were not 
Table 1. Information regarding vegetation, $\mathrm{C}$ and $\mathrm{N}$ pool, $\mathrm{pH}$, soil moisture (5th and 95 th percentiles) and depth to water table at the individual chamber locations. Chamber locations were named $U_{1}-U_{5}$ at the undisturbed plot, $T_{1}-T_{4}$ at the thinned plot, $C_{1}-C_{5}$ at the clear-cut plot and $S_{1}-S_{5}$ at the stump harvested plot.

\begin{tabular}{|c|c|c|c|c|c|c|c|}
\hline ID & Time period & Vegetation/bare soil & $\begin{array}{l}\text { Carbon }^{\mathrm{a}} \\
\left(\mathrm{kg} \mathrm{m}^{-2}\right)\end{array}$ & $\begin{array}{l}\text { Nitrogen }^{\mathrm{a}} \\
\left(\mathrm{kg} \mathrm{m}^{-2}\right)\end{array}$ & $\mathrm{pH}^{\mathrm{b}}$ & $\begin{array}{l}\text { Soil moisture } \\
(\%)\end{array}$ & $\begin{array}{l}\text { Depth to } \\
\text { water table } \\
(\mathrm{cm})\end{array}$ \\
\hline$T_{1}$ & 1 Aug 2009-31 May 2010 & Mosses, bilberry & 6.7 & 0.22 & 3.1 & $28.8-45.8$ & $54-154$ \\
\hline$T_{2}$ & 1 Aug 2009-31 May 2010 & Mosses, bilberry & 5.0 & 0.17 & 3.1 & $25.0-40.0$ & $44-144$ \\
\hline$T_{3}$ & 1 Aug 2009-31 May 2010 & Mosses, bilberry & 5.5 & 0.24 & 3.5 & $33.5-55.6$ & $15-116$ \\
\hline$T_{4}$ & 11 Dec 2009-31 May 2010 & Mosses, bilberry & 3.3 & 0.10 & 3.0 & $19.2-36.3$ & $29-129$ \\
\hline$U_{1}$ & 7 Jul 2010-4 Oct 2010 & Mosses, bilberry & 2.6 & 0.17 & 3.3 & $6.0-27.3$ & $120-173$ \\
\hline$U_{2}$ & 7 Jul 2010-4 Oct 2010 & Mosses, bilberry & 6.1 & 0.29 & 3.2 & $10.0-33.4$ & $107-160$ \\
\hline$U_{3}$ & 7 Jul 2010-4 Oct 2010 & Mosses, bilberry & No data & No data & No data & $9.4-37.0$ & $102-155$ \\
\hline$U_{4}$ & 7 Jul 2010-4 Oct 2010 & Mosses, bilberry & 2.3 & 0.09 & 3.3 & $6.6-32.9$ & $136-190$ \\
\hline$U_{5}$ & 7 Jul $2010-4$ Oct 2010 & Mosses, bilberry & 3.9 & 0.15 & 3.4 & $7.8-23.5$ & $132-185$ \\
\hline$S_{1}$ & 7 Oct $2010-20$ Oct 2010 & Mosses, bilberry & 14.1 & 0.45 & 4.4 & $42.0-42.9$ & $20-21$ \\
\hline$S_{2}$ & 7 Oct $2010-20$ Oct 2010 & $\begin{array}{l}\text { Bare soil, mixed organic and } \\
\text { mineral soil layers }\end{array}$ & 6.0 & 0.19 & 4.4 & $23.4-25.3$ & $31-32$ \\
\hline$S_{3}$ & 7 Oct $2010-20$ Oct 2010 & $\begin{array}{l}\text { Bare soil, mixed organic and } \\
\text { mineral soil layers }\end{array}$ & 19.0 & 0.62 & 4.4 & $30.0-33.2$ & $47-48$ \\
\hline$S_{4}$ & 7 Oct $2010-20$ Oct 2010 & $\begin{array}{l}\text { Some vegetation and thick } \\
\text { litter layer }\end{array}$ & No data & No data & No data & $35.9-39.4$ & $35-36$ \\
\hline$S_{5}$ & 7 Oct $2010-20$ Oct 2010 & $\begin{array}{l}\text { No vegetation and thick litter } \\
\text { layer }\end{array}$ & No data & No data & No data & $33.7-36.1$ & $37-38$ \\
\hline$C_{1}$ & 21 Oct 2010-9 Nov 2010 & Mosses, bilberry & 4.7 & 0.16 & 4.2 & $41.5-46.2$ & $44-50$ \\
\hline$C_{2}$ & 21 Oct 2010-9 Nov 2010 & $\begin{array}{l}\text { Bare soil, mixed organic and } \\
\text { mineral soil layers }\end{array}$ & 13.1 & 0.41 & 4.2 & $44.2-50.3$ & $6-12$ \\
\hline$C_{3}$ & 21 Oct 2010-9 Nov 2010 & $\begin{array}{l}\text { Bare soil, mixed organic and } \\
\text { mineral soil layers }\end{array}$ & 11.9 & 0.35 & 4.2 & No data & $7-13$ \\
\hline$C_{4}$ & 21 Oct 2010-9 Nov 2010 & Mosses, bilberry & 9.5 & 0.30 & 4.2 & $56.6-57.6$ & $6-13$ \\
\hline$C_{5}$ & 21 Oct 2010-9 Nov 2010 & $\begin{array}{l}\text { Bare soil, mixed organic and } \\
\text { mineral soil layers }\end{array}$ & 11.5 & 0.36 & 4.2 & $49.5-49.9$ & $0-1$ \\
\hline
\end{tabular}

${ }^{\mathrm{a}} \mathrm{C}$ and $\mathrm{N}$ pool to a depth of $20 \mathrm{~cm}$ in the mineral soil (litter layer excluded). ${ }^{\mathrm{b}} \mathrm{pH}\left(\mathrm{BaCl}_{2}\right)$ for the undisturbed and thinned plots, and $\mathrm{pH}\left(\mathrm{H}_{2} \mathrm{O}\right)$ for the clear-cut and stump harvested plots, were measured at a $0-10 \mathrm{~cm}$ depth in the mineral soil.

disturbed by site preparation, but plot $S_{4}$ was a $\mathrm{CH}_{4}$ sink, while plot $\mathrm{S}_{5}$ was a $\mathrm{CH}_{4}$ source (Fig. 4).

At the majority of the measurement locations on the clearcut and stump harvested plots, higher temperatures correlated significantly $(p<0.05)$ with lower $\mathrm{CH}_{4}$ emissions, or, in one case, with a higher net uptake. Both negative and positive significant correlations between $\mathrm{CH}_{4}$ exchange and soil moisture were found at a few measurement locations, but the soil moisture range at those measurement locations was very small. At two measurement locations with net emissions at the clear-cut plot, there was a significant $(p<0.05)$ negative correlation between $\mathrm{CH}_{4}$ exchange and water table depth, so that a deeper water table depth gave higher $\mathrm{CH}_{4}$ emissions (Table 2). The multiple linear regression confirmed the significantly negative correlation between $\mathrm{CH}_{4}$ exchange and temperature at six measurement locations.

\section{Discussion}

All measurement locations at the undisturbed forest plot were sinks of $\mathrm{CH}_{4}$ throughout the measurement period, which is consistent with the generally drained, drier and warmer soil conditions at the plot (Fig. 2). The measurement locations at the thinned plot were also net sinks of $\mathrm{CH}_{4}$, although reduced in comparison to the undisturbed plot. By contrast, the clear-cut and stump harvested plots were net sources of $\mathrm{CH}_{4}$. Since the measurements at the different plots were conducted at different times of the year, seasonality and annual variations can probably explain some of the differences in $\mathrm{CH}_{4}$ exchange and soil conditions. However, it is not likely that differences in water table depth between the plots are due solely to seasonal variations. In the autumn of 2010, the water table was, on average, more than $1 \mathrm{~m}$ higher at the clearcut and stump harvested plots than at the undisturbed plot. In addition to this, the mean $\mathrm{CH}_{4}$ exchange for the autumn period October to November at the thinned site did not differ much from the mean $\mathrm{CH}_{4}$ exchange for the whole measurement period, indicating that average seasonal variations are small (Fig. 2). Precipitation was, on average, higher during the measurement period at the thinned site than during measurements at the other plots, which did not cause a switch from $\mathrm{CH}_{4}$ sink to $\mathrm{CH}_{4}$ source. The clear-cut and stump harvested plots are located on a plateau, which is uphill from the thinned and undisturbed plots, and hence topography should 

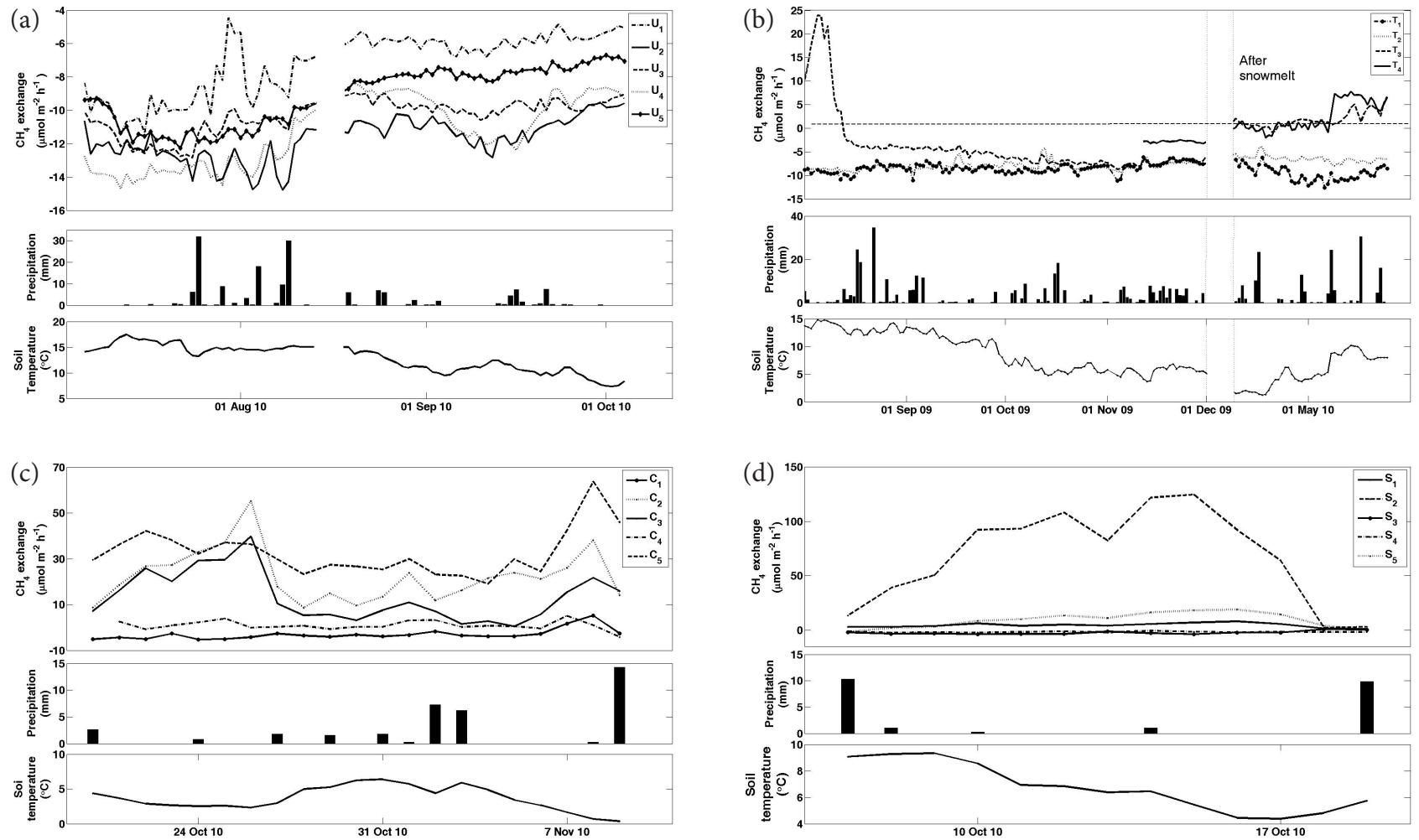

Figure 3. Time series of daily mean $\mathrm{CH}_{4}$ exchange, daily precipitation and daily mean soil temperature at the measurement locations. (a) Undisturbed plot; (b) thinned plot; (c) clear-cut plot; (d) stump harvested plot.

not be responsible for the higher water table at the clear-cut and stump harvested plots (Fig. 1).

Water table depth, soil moisture and soil temperature were all shown to be important drivers of $\mathrm{CH}_{4}$ exchange, as demonstrated by the linear and multiple linear regression analyses. However, it appears that the rise of the water table and increased soil moisture caused some of the measurement locations to shift to $\mathrm{CH}_{4}$ sources. This is consistent with results by Zerva and Menucuccini (2005) and Castro et al. (2000). Temporal shifts to $\mathrm{CH}_{4}$ emissions after snowmelt and summer precipitation, as were seen at measurement locations $T_{3}$ and $T_{4}$, were also reported by Wang and Bettany (1995).

A majority of net emitting measurement locations at the clear-cut and stump harvested plots $\left(C_{2}, C_{3}, C_{4}, C_{5}, S_{1}\right)$ were positioned less than $21 \mathrm{~cm}$ above the water table, and had a volumetric soil moisture content above $40 \%$ (Table 1). Measurement location $T_{3}$, when it had temporarily shifted to a $\mathrm{CH}_{4}$ source, also had volumetric soil moisture content above $40 \%$. Net emissions were also measured at measurement locations $S_{2}$ and $S_{5}$ with water table depths at $30-40 \mathrm{~cm}$ and volumetric soil moisture contents of $23-40 \%$. Fiedler and Sommer (2000) found a threshold value of water table depth at $15 \mathrm{~cm}$, below which only minor annual emissions were measured. The three measurement locations at the clear-cut and stump harvested plots that showed net consumption of
$\mathrm{CH}_{4}$ were further than average above the water table for those plots (Fig. 4).

Temperature seemed to have a stronger impact on $\mathrm{CH}_{4}$ exchange in drier conditions. Figure 5 illustrates a high correlation $\left(r^{2}=0.74\right)$ between soil temperature and $\mathrm{CH}_{4}$ exchange at measurement location $U_{4}$ when excluding data points with soil moisture above $22 \%$ and a distance to the water table of less than $1.25 \mathrm{~m}$. The threshold value of $22 \%$ was selected after visual inspection of the data. If all of the data from wetter conditions were included (volumetric soil moisture content $>22 \%$ and water table $<1.25 \mathrm{~m}$ away), the corresponding $r^{2}$ would equal 0.47 . This is consistent with the results from the multiple linear regression analyses showing that water table depth had a significant impact on the $\mathrm{CH}_{4}$ exchange at all measurement locations in August 2010, when the water table depth varied strongly. In contrast, throughout September, there were no major precipitation events, and soil temperature was the most influential variable. Soil moisture was rarely below $30 \%$ at the thinned plot, thus the temperature dependence was less. In autumn (September to November 2009), all measurement locations at the thinned plot were stable sinks of $\mathrm{CH}_{4}$, even though the soil temperature was, at times, below $5^{\circ} \mathrm{C}$.

At the clear-cut and stump harvested plots, where most measurement locations were net sources of $\mathrm{CH}_{4}$, we would expect a positive correlation between soil temperature and 
Table 2. Correlation coefficients $\mathrm{C}$ and corresponding $\mathrm{P}$ values for the linear regressions between $\mathrm{CH}_{4}$ exchange and soil temperature, soil moisture and water table depth. The $r^{2}$ shows how well the combined variables explain the variance in the $\mathrm{CH}_{4}$ exchange. The correlation analyses are based on data from the entire measurement period.

\begin{tabular}{lrrrrrrr}
\hline & $\begin{array}{r}\mathrm{C} \\
\text { Soil }\end{array}$ & $\begin{array}{r}\mathrm{P} \\
\text { Soil }\end{array}$ & $\begin{array}{r}\mathrm{C} \\
\text { Soil }\end{array}$ & $\begin{array}{r}\mathrm{P} \\
\text { Soil } \\
\end{array}$ & $\begin{array}{r}\text { Water table } \\
\text { depth }\end{array}$ & $\begin{array}{r}\text { Water table } \\
\text { depth }\end{array}$ \\
\hline$T_{1}$ & -0.09 & $* *$ & 0.57 & $* *$ & 0.12 & $* *$ & 0.27 \\
$T_{2}$ & -0.34 & $* *$ & -0.23 & $* *$ & 0.46 & $* *$ & 0.26 \\
$T_{3}$ & 0.34 & $* *$ & 0.72 & $* *$ & 0.45 & $* *$ & 0.61 \\
$T_{4}$ & 0.28 & $* *$ & -0.72 & $* *$ & 0.54 & $* *$ & 0.68 \\
$U_{1}$ & -0.61 & $* *$ & 0.48 & $* *$ & 0.51 & $* *$ & 0.47 \\
$U_{2}$ & -0.63 & $* *$ & 0.39 & $* *$ & 0.54 & $* *$ & 0.47 \\
$U_{3}$ & -0.57 & $* *$ & 0.44 & $* *$ & 0.55 & $* *$ & 0.53 \\
$U_{4}$ & -0.69 & $* *$ & 0.54 & $* *$ & 0.70 & $* *$ & 0.78 \\
$U_{5}$ & -0.82 & $* *$ & 0.54 & $* *$ & 0.69 & $* *$ & 0.81 \\
$S_{1}$ & -0.35 & $* *$ & -0.18 & $*$ & No data & No data & 0.09 \\
$S_{2}$ & -0.16 & $*$ & -0.10 & 0.09 & No data & No data & 0.07 \\
$S_{3}$ & -0.02 & 0.82 & -0.09 & 0.21 & No data & No data & 0.002 \\
$S_{4}$ & -0.16 & $*$ & -0.009 & 0.9 & No data & No data & 0.05 \\
$S_{5}$ & -0.34 & $* *$ & -0.46 & $*$ & No data & No data & 0.09 \\
$C_{1}$ & -0.06 & 0.29 & -0.13 & $*$ & 0.03 & 0.54 & 0.14 \\
$C_{2}$ & -0.52 & $* *$ & 0.25 & $* *$ & -0.07 & 0.13 & 0.22 \\
$C_{3}$ & -0.57 & $* *$ & No data & No data & -0.47 & $* *$ & 0.46 \\
$C_{4}$ & -0.04 & 0.57 & 0.04 & 0.57 & -0.01 & 0.91 & 0.01 \\
$C_{5}$ & -0.54 & $* *$ & -0.03 & 0.54 & -0.20 & $* *$ & 0.21 \\
\hline
\end{tabular}

** significant: $p<0.001$; ${ }^{*}$ significant: $p<0.05$; no data: At the time for measurements on the stump harvested plot, the water table depth was only measured manually on a few occasions and therefore no linear regression could be made for this period.

Table 3. Coefficients from multiple linear regression analyses. A value is given only if the variable significantly contributes to explain the variation in the $\mathrm{CH}_{4}$ exchange. The $r^{2}$ shows how well the combined variables explain the variance in the $\mathrm{CH}_{4}$ exchange. S.m represents soil moisture, S.t denotes soil temperature, W.t shows water table depth and n.d means no data is available.

\begin{tabular}{|c|c|c|c|c|c|c|c|c|c|c|c|c|c|c|c|c|c|c|c|c|}
\hline & \multicolumn{4}{|c|}{$T_{1}$} & \multicolumn{4}{|c|}{$T_{2}$} & \multicolumn{4}{|c|}{$T_{3}$} & \multicolumn{4}{|c|}{$T_{4}$} & & & & \\
\hline & $r^{2}$ & S.m. & S.t. & W.t. & $r^{2}$ & S.m. & S.t. & W.t. & $r^{2}$ & S.m. & S.t. & W.t. & $r^{2}$ & S.m. & S.t. & W.t. & & & & \\
\hline Aug 2009 & 0.58 & 0.61 & - & 0.43 & 0.24 & 0.14 & -0.18 & 0.44 & 0.76 & 0.66 & 0.33 & - & n.d & n.d & n.d & n.d & & & & \\
\hline Sep 2009 & 0.10 & 0.31 & - & - & 0.10 & - & -0.28 & - & 0.28 & 0.52 & - & - & n.d & n.d & n.d & n.d & & & & \\
\hline Oct 2009 & 0.18 & 0.27 & -0.14 & 0.22 & 0.16 & -0.28 & -0.28 & -0.20 & 0.10 & -0.15 & 0.13 & -0.21 & n.d & n.d & n.d & n.d & & & & \\
\hline Nov 2009 & 0.31 & 0.44 & -0.16 & 0.33 & 0.23 & 0.33 & -0.44 & 0.43 & 0.33 & - & 0.13 & 0.50 & 0.04 & - & 0.20 & - & & & & \\
\hline Apr 2010 & 0.31 & 0.54 & 0.39 & 0.34 & 0.27 & 0.65 & -0.34 & -0.59 & 0.10 & - & -0.26 & - & n.d & n.d & n.d & n.d & & & & \\
\hline \multirow[t]{3}{*}{ May 2010} & 0.22 & 0.43 & - & -0.18 & 0.10 & - & -0.29 & - & 0.38 & -0.49 & - & 0.46 & 0.62 & n.d & 0.79 & n.d & & & & \\
\hline & \multicolumn{3}{|l|}{$U_{1}$} & \multicolumn{5}{|c|}{$U_{2}$} & \multicolumn{3}{|c|}{$U_{3}$} & \multicolumn{4}{|c|}{$U_{4}$} & \multicolumn{4}{|c|}{$U_{5}$} & \\
\hline & $r^{2}$ & S.m. & S.t. & W.t. & $r^{2}$ & S.m. & S. t. & W.t. & $r^{2}$ & S.m. & S.t. & W.t. & $r^{2}$ & S.m. & S.t. & W.t. & $r^{2}$ & S.m. & S.t. & W.t. \\
\hline Jul 2010 & 0.22 & 0.42 & - & -0.18 & 0.10 & n.d & -0.24 & 0.22 & 0.42 & 0.60 & -0.14 & 0.48 & 0.12 & 0.12 & -0.28 & - & 0.49 & 0.20 & -0.27 & 0.48 \\
\hline Aug 2010 & 0.47 & - & -0.12 & 0.62 & 0.56 & n.d & -0.23 & 0.61 & 0.37 & 0.08 & - & 0.60 & 0.80 & 0.19 & -0.18 & 0.79 & 0.78 & 0.15 & -0.34 & 0.63 \\
\hline \multirow[t]{3}{*}{ Sep 2010} & 0.12 & 0.10 & -0.29 & -0.10 & 0.37 & n.d & -0.60 & - & 0.10 & 0.11 & -0.23 & -0.10 & 0.63 & 0.46 & -0.50 & - & 0.28 & - & -0.51 & -0.10 \\
\hline & & $S_{1}$ & & & $S_{2}$ & & & $S_{3}$ & & & $S_{4}$ & & & $S_{5}$ & & & & & & \\
\hline & $r^{2}$ & S.m. & S.t. & $r^{2}$ & S.m. & S.t. & $r^{2}$ & S.m. & S.t. & $r^{2}$ & S.m. & S.t. & $r^{2}$ & S.m. & S.t. & & & & & \\
\hline \multirow[t]{3}{*}{ Oct 2010} & 0.09 & - & -0.29 & 0.07 & -0.27 & - & 0.002 & - & - & 0.05 & 0.10 & 0.10 & 0.09 & - & -0.28 & & & & & \\
\hline & \multicolumn{4}{|c|}{$C_{1}$} & \multicolumn{4}{|c|}{$C_{2}$} & \multicolumn{4}{|c|}{$C_{3}$} & \multicolumn{4}{|c|}{$C_{4}$} & \multicolumn{4}{|c|}{$C_{5}$} \\
\hline & $r^{2}$ & S.m. & S.t. & W.t. & $r^{2}$ & S.m. & S.t. & W.t. & $r^{2}$ & S.m. & S.t. & W.t. & $r^{2}$ & S.m. & S.t. & W.t. & $r^{2}$ & S.m. & S.t. & W.t. \\
\hline Oct-Nov 2010 & 0.14 & - & -0.32 & - & 0.22 & 0.29 & -0.34 & -0.38 & 0.46 & n.d & -0.44 & -0.44 & 0.01 & - & - & - & 0.21 & -0.28 & -0.59 & 0.12 \\
\hline
\end{tabular}

$\mathrm{CH}_{4}$ exchange, so that higher temperatures led to higher net emissions of $\mathrm{CH}_{4}$. Methanogens generally respond better than methanotrophs to increased temperatures (Dunfield et al., 1993). However, this was not the case; a majority of the measurement locations showed a significantly negative correlation between temperature and $\mathrm{CH}_{4}$ exchange. The result is difficult to explain since $\mathrm{CH}_{4}$ production and oxidation are not measured separately. Soil temperature profiles at the clear-cut and stump harvested plots (data not shown) show that, during the measurement period, changes 


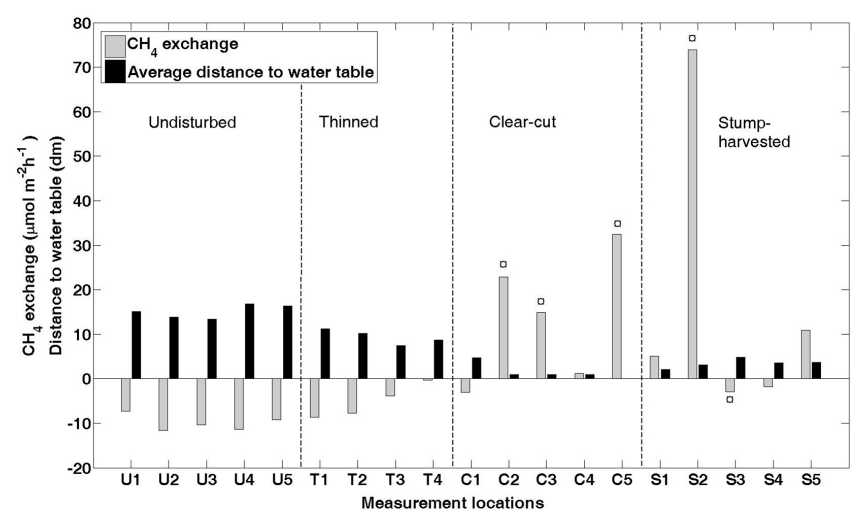

Figure 4. $\mathrm{CH}_{4}$ exchange $\left(\mu \mathrm{mol} \mathrm{m} \mathrm{m}^{-2} \mathrm{~h}^{-1}\right)$ at all individual measurement locations with associated level of groundwater table. The water table depth at plot $C_{5}$ is close to zero and that is why the bar is not visible in the diagram. $\square$ Measurement locations at which soil surface was disturbed during site preparation.

in surface temperature, associated with periods of cloudy conditions and precipitation, at a $5 \mathrm{~cm}$ depth are larger than those at a 20 and $40 \mathrm{~cm}$ depth. Methanotrophs are expected to be located closer to the soil surface than methanogens, and the larger temperature increase at the surface might compensate their lower response to temperature, which could explain why net $\mathrm{CH}_{4}$ exchange is negatively correlated to soil temperature during this period.

The highest $\mathrm{CH}_{4}$ emissions were found at four of the five disturbed measurement locations; that is, at sites of bare soil where organic and mineral soils were mixed. The soil at disturbed measurement locations seemed less compact than at measurement locations with intact vegetation, so the disturbance probably did not inhibit diffusion. The availability of fresh organic material was possibly higher at disturbed measurement locations. Fresh, labile organic matter would promote heterotrophic uptake of $\mathrm{O}_{2}$ and increase the soil's water retention, thereby promoting the activity of methanogenic archaeans (Wachinger et al., 2000). The one disturbed measurement location, which showed net $\mathrm{CH}_{4}$ consumption, $\mathrm{S}_{3}$, was positioned on top of a mound with a relatively large distance to the groundwater table (Fig. 4).

Since this is a study of the short-term effects of forest management practices on $\mathrm{CH}_{4}$ exchange, there are no data on how long-lived these effects are. Sudden shifts from sinks to sources and back again, due to changes in soil water conditions, are evident, as we have seen at the thinned plot (Fig. 3b). It might take years (Tate et al., 2006) to several decades for a soil to regain its full sink capacity. The recovery time for the soil $\mathrm{CH}_{4}$ sink strength of forests on abandoned agricultural land was more than 100 years (Prieme et al., 1997; Smith et al., 2000). Increasing $\mathrm{CH}_{4}$ uptake with time after afforestation can be an effect of an increase in the population of $\mathrm{CH}_{4}$ oxidizing bacteria with time (Bárcena et al., 2014) or better soil diffusivity and soil aeration with time

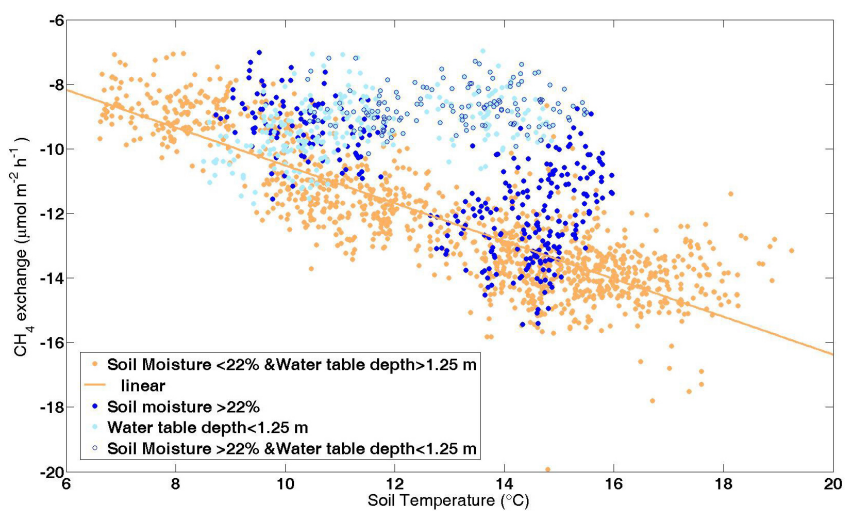

Figure 5. Correlation between $\mathrm{CH}_{4}$ exchange $\left(\mu \mathrm{mol} \mathrm{m}{ }^{-2} \mathrm{~h}^{-1}\right)$ and soil temperature $\left({ }^{\circ} \mathrm{C}\right)$ at measurement location $U_{4}$. The different colours represent different soil moisture and water table depths.

(Christiansen and Gundersen, 2011; Peichl et al., 2010). A better soil aeration with time could be due to an increase in root biomass, which means that the roots loosen the soil over time and absorb more water (Peichl et al., 2010). Hiltbrunner et al. (2012) found that the soil $\mathrm{CH}_{4}$ sink capacity of abandoned agricultural land increased with stand age up to 120 years. This was due to the increased transpiration of older forests and their ability to shield the forest floor from precipitation, which resulted in more favourable conditions for methanotrophic activity.

Uptake rates by forest landscapes might be overestimated (Grunwald et al., 2012; Fiedler et al., 2005). A study by Grunwald et al. (2012) found that wet forests were as important as wetlands for the $\mathrm{CH}_{4}$ budget of European forests. Fiedler et al. (2005) found that, if $2.3 \%$ of a forest area consisted of wet soil, the forest could turn from a sink to a source of $\mathrm{CH}_{4}$. As mentioned, after clear-cutting, water table depth decreased and soil moisture increased. Wetter soils and a higher groundwater table are common consequences of clear-cutting, and it is therefore important to consider their impact on the $\mathrm{CH}_{4}$ budget in managed forests, especially if the recovery time for the soil $\mathrm{CH}_{4}$ sink is several decades. In this study, the effects of thinning on the $\mathrm{CH}_{4}$ exchange were not as pronounced as those for clear-cutting, although the plot average consumption was reduced in comparison to the undisturbed plot. Any forest management practice that reduces disturbance and leaves a continuous forest cover might be a better alternative from a global-warming perspective.

\section{Conclusions}

Our study on the short-term effects of boreal forest management on $\mathrm{CH}_{4}$ exchange shows that the undisturbed plot and the thinned plot remained net $\mathrm{CH}_{4}$ sinks, while the clearcut and stump harvested plots were net $\mathrm{CH}_{4}$ sources. Linear regression analyses between $\mathrm{CH}_{4}$ exchange and climatic 
variables showed that, for most measurement locations at the undisturbed and thinned plots, net $\mathrm{CH}_{4}$ uptake increased significantly with decreasing soil moisture, decreasing water table depth and increasing temperatures. A higher water table and increased soil moisture were likely to be responsible for the shift to $\mathrm{CH}_{4}$ emissions at the clear-cut and stump harvested plots. At most of the measurement locations, which showed net emissions, the soil was almost saturated and the water table was within a few decimetres of the soil surface. Clear-cutting of the forest resulted in a raised groundwater table and increased soil moisture. These effects should be accounted for in the $\mathrm{CH}_{4}$ budget of managed forests.

Acknowledgements. Support for this work was provided by Formas and by the Linnaeus Centre LUCCI (http://www.lucci.lu.se/index.html) funded by the Swedish Research Council. Airborne LiDAR for the Norunda site, the basis for the digital elevation model, was acquired with support from the British Natural Environment Research Council (NERC/ARSF/FSF grant EU10-01 and NERC/GEF grant 933). We thank Anders Båth and Tomas Karlsson for their field assistance.

Edited by: U. Seibt

\section{References}

Bárcena, T.G., D’Imperio, L., Gundersen, P., Vesterdal, L., Priemé, A., and Christiansen, J. R.: Conversion of cropland to forest increases soil $\mathrm{CH} 4$ oxidation and abundance of $\mathrm{CH} 4$ oxidizing bacteria with stand age, Appl. Soil. Ecol., 79, 49-58, 2014.

Bradford, M. A., Ineson, P., Wookey, P. A., and Lappin-Scott, H. M.: Soil CH4 oxidation: response to forest clearcutting and thinning, Soil Biol. Biochem., 32, 1035-1038, 2000.

Castro, M. S., Gholz, H. L., Clark, K. K., and Steudler, P. A.: Effects of forest harvesting on soil methane fluxes in Florida slash pine plantations, Can. J. Forest. Res., 30, 1534-1542, 2000.

Christiansen, J. R. and Gundersen, P.: Stand age and tree species affect $\mathrm{N}_{2} \mathrm{O}$ and $\mathrm{CH}_{4}$ exchange from afforested soils, Biogeosciences, 8, 2535-2546, doi:10.5194/bg-8-2535-2011, 2011.

Dannenmann, M., Gasche, R., Ledebuhr, A., Holst, T., Mayer, H., and Papen, H.: The effect of forest management on trace gas exchange at the pedosphere-atmosphere interface in beech (Fagus sylvatica L.) forests stocking on calcareous soils., Eur. J. Forest Res., 126, 331-346, 2007.

Dunfield, P., Knowles, R., Dumont, R., and Moore, T. R.: Methane production and consumption in temperature and sub-arctic pear soils-response to temperature and $\mathrm{pH}$, Soil Biol. Biochem., 25, 321-326, 1993.

Dutaur, L. and Verchot, L. V.: A global inventory of the soil $\mathrm{CH}(4)$ sink, Global Biogeochem. Cy., 21, GB4013, doi:10.1029/2006GB002734, 2007.

Ehhalt, D. H.: Atmospheric cycle of methane, TELLUS, 26, 58-70, 1974.

Fiedler, S. and Sommer, M.: Methane emissions, groundwater levels and redox potentials of common wetland soils in a temperatehumid climate, Global Biogeochem. Cy., 14, 1081-1093, 2000.
Fiedler, S., Holl, B. S., and Jungkunst, H. F.: Methane budget of a Black Forest spruce ecosystem considering soil pattern, Biogeochemistry, 76, 1-20, 2005.

Grunwald, D., Fender, A. C., Erasmi, S., and Jungkunst, H. F.: Towards improved bottom-up inventories of methane from the European land surface, Atmos. Environ., 51, 203-211, 2012.

Gulledge, J. and Schimel, J. P.: Moisture control over atmospheric $\mathrm{CH} 4$ consumption and $\mathrm{CO}_{2}$ production in diverse Alaskan soils, Soil Biol. Biochem., 30, 1127-1132, 1998

Harriss, R. C., Sebacher, D. I., and Day, F. P.: Methane flux in the great dismal swamp, Nature, 297, 673-674, 1982.

Hiltbrunner, D., Zimmermann, S., Karbin, S., Hagedorn, F., and Niklaus, P. A.: Increasing soil methane sink along a 120-year afforestation chronosequence is driven by soil moisture, Glob. Change Biol., 18, 3664-3671, 2012.

Hutsch, B. W., C. P. Webster, and Powlson D. S.: Long term effects of nitrogen-fertilization on methane oxidation in soil of the broadbalk wheat experiment, Soil Biol. Biochem., 25, 1307-1315, 1993.

Huttunen, J. T., Nykanen, H., Martikainen, P. J., and Nieminen, M., Fluxes of nitrous oxide and methane from drained peatlands following forest clear-felling in southern Finland, Plant Soil., 255, 457-462, 2003.

Kagotani, Y., Hamabata, E., and Nakajima, T.: Seasonal and spatial variations and the effects of clear-cutting in the methane absorption rates of a temperate forest soil, Nutr. Cycl. Agroecosys., 59, 169-175, 2001.

Kammann, C., Hepp, S., Lenhart, K., and Muller, C.: Stimulation of methane consumption by endogenous $\mathrm{CH}_{4}$ production in aerobic grassland soil, Soil Biol. Biochem., 41, 622-629, 2009.

Keller, M., Varner, R., Dias, J. D., Silva, H., Crill, P., and de Oliveira, R. C.: Soil-atmosphere exchange of nitrous oxide, nitric oxide, methane, and carbon dioxide in logged and undisturbed forest in the Tapajos National Forest, Brazil, Earth Interact., 9, $1-28,2005$.

Kirschke, S., Bousquet, P., Ciais, P. Saunois, M., Canadell, J. G., Dlugokencky, E. J., Bergamaschi, P., Bergmann, D., Blake, D. R., Bruhwiler, L., Cameron-Smith, P., Castaldi, S., Chevallier, F., Feng, L., Fraser, A., Heimann, M., Hodson, E. L., Houweling, S., Josse, B., Fraser, P. J., Krumme, P. B., Lamarque, J.F., Langenfelds, R. L., Quéré, C. L., Naik, V., O'Doherty, S., Palmer, P. I., Pison, I., Plummer, D., Poulter, B., Prinn, R. G., Rigby, M., Ringeval1, B., Santini, M., Schmidt, M., Shindell, D. T., Simpson, I. J., Spahni, R., Steele, L. P., Strode, S. A., Sudo, S., Szopa, S., van der Werf, G. R., Voulgarakis, A., van Weele, M., Weiss, R. F., Williams, J. E., and Zeng, G.: Three decades of global methane sources and sinks. NAT GEOSCI, 6, 813-823, 2013.

Koschorreck, M. and Conrad, R.: Oxidation of atmospheric methane in soil-measurements in the field, in soil cores and in soil samples, Global Biogeochem. Cy., 7, 109-121, 1993.

Le Mer, J. and Roger, P.: Production, oxidation, emission and consumption of methane by soils: A review, Eur. J. Soil Biol., 37, 25-50, 2001.

Lundin, L. C., Halldin, S., Lindroth, A., Cienciala, E., Grelle, A., Hjelm, P., Kellner, E., Lundberg, A., Molder, M., Moren, A. S., Nord, T., Seibert, J., and Stahli, M.: Continuous long-term measurements of soil-plant-atmosphere variables at a forest site, Agr. Forest Meteorol., 98, 53-73, 1999. 
Megonigal, J. P. and Guenther, A. B.: Methane emissions from upland forest soils and vegetation, Tree Physiol., 28, 491-498, 2008.

Mojeremane, W., Rees, R. M., and Mencuccini, M.: Effects of site preparation for afforestation on methane fluxes at Harwood Forest, NE England, Biogeochemistry, 97, 89-107, 2010.

Mojeremane, W., Rees, R. M., and Mencuccini, M.: The effects of site preparation practices on carbon dioxide, methane and nitrous oxide fluxes from a peaty gley soil, Forestry, 85, 1-15, 2012.

Ojima, D. S., Valentine, D. W., Mosier, A. R., Parton, W. J., and Schimel, D. S.: Effect of land-use change on methane oxidation in temperate forest and grassland soils, Chemosphere, 26, 675-685, 1993.

Peichl, M., Arain, M. A., Ullah, S., and Moore, T. R.: Carbon dioxide, methane, and nitrous oxide exchanges in an age-sequence of temperate pine forests, Glob. Change Biol., 16, 2198-2212, 2010.

Prieme, A., Christensen, S., Dobbie, K. E., and Smith, K. A.: Slow increase in rate of methane oxidation in soils with time following land use change from arable agriculture to woodland, Soil Biol. Biochem., 29, 1269-1273, 1997.

Shindell, D. T., Faluvegi, G., Koch, D. M., Schmidt, G. A., Unger, N., and Bauer, S. E.: Improved Attribution of Climate Forcing to Emissions, Science, 326, 716-718, 2009.

Smith, K. A., Dobbie, K. E., Ball, B. C., Bakken, L. R., Sitaula, B. K., Hansen, S., Brumme, R., Borken, W., Christensen, S., Prieme, A., Fowler, D., Macdonald, J. A., Skiba, U., Klemedtsson, L., Kasimir-Klemedtsson, A., Degorska, A., and Orlanski, P.: Oxidation of atmospheric methane in Northern European soils, comparison with other ecosystems, and uncertainties in the global terrestrial sink, Glob. Change Biol., 6, 791-803, 2000.

Smolander, A., Priha, O., Paavolainen, L., Steer, J., and Malkonen, E.: Nitrogen and carbon transformations before and after clearcutting in repeatedly $\mathrm{N}$-fertilized and limed forest soil, Soil Biol. Biochem., 30, 477-490, 1998.

Steudler, P. A., Bowden, R. D., Melillo, J. M., and Aber, J. D.: Influence of nitrogen-fertilization on methane uptake in temperate forest soils, Nature, 341, 314-316, 1989.

Steudler, P. A., Melillo, J. M., Bowden, R. D., Castro, M. S., and Lugo, A. E.: The effects of natural and human disturbances on soil-nitrogen dynamics and trace gas fluxes in a Puerto-Rican wet forest, Biotropica, 23, 356-363 1991.

Sullivan, B., Kolb, T. E., Hart, S. C., Kaye, J. P., Dore, S., and Montes-Helu, M.: Thinning reduces soil carbon dioxide but not methane flux from southwestern USA ponderosa pine forests, For. Ecol. Manag., 255, 4047-4055, 2008.
Tate, K. R., Ross, D. J., Scott, N. A., Rodda, N. J., Townsend, J. A., and Arnold, G. C.: Post-harvest patterns of carbon dioxide production, methane uptake and nitrous oxide production in a Pinus radiata D, Don plantation, For. Ecol. Manag., 228, 40-50, 2006.

Teepe, R., Brumme, R., Beese, F., and Ludwig, B.: Nitrous oxide emission and methane consumption following compaction of forest soils, Soil Sci. Soc. Am. J.,68, 605-611, 2004.

Thibodeau, L., Raymond, P., Camire, C., and Munson, A. D.: Impact of precommercial thinning in balsam fir stands on soil nitrogen dynamics, microbial biomass, decomposition, and foliar nutrition, Can. J. Forest Res., 30, 229-238, 2000.

Van Amstel, A.: Methane, A review, J INTEGR ENVIRON SCI, 9, 5-30, 2012.

Verchot, L. V., Davidson, E. A., Cattanio, J. H., and Ackerman, I. L.: Land-use change and biogeochemical controls of methane fluxes in soils of eastern Amazonia, Ecosystems, 3, 41-56, 2000.

von Fischer, J. C. and Hedin, L. O.: Separating methane production and consumption with a field-based isotope pool dilution technique, Global Biogeochem. Cy., 16, 8/1-8/13, 2002.

Wachinger, G., Fiedler, S., Zepp, K., Gattinger, A., Sommer, M., and Roth, K.: Variability of soil methane production on the micro-scale: spatial association with hot spots of organic material and Archaeal populations, Soil Biol. Biochem., 32, 1121-1130, 2000.

Wang, F.L. and Bettany, J. R.: Methane emissions from a usually well-drained prairie soil after snowmelt and precipitation, Can. J. Soil Sci., 75, 239-241, 1995.

Wang, Z. P. and Ineson, P.: Methane oxidation in a temperate coniferous forest soil: effects of inorganic N, Soil Biol. Biochem., 35, 427-433, 2003.

Whalen, S. C. and Reeburgh, W. S.: Consumption of atmospheric methane by tundra soils, Nature, 346, 160-162, 1990.

Whalen, S. C. and Reeburgh, W. S.: Moisture and temperature sensitivity of $\mathrm{CH}_{4}$ oxidation in boreal soils, Soil Biol. Biochem., 28, 1271-1281, 1996.

Wu, X., Bruggemann, N., Gasche, R., Papen, H., Willibald, G., and Butterbach-Bahl, K.: Long-term effects of clear-cutting and selective cutting on soil methane fluxes in a temperate spruce forest in southern Germany, Environ. Pollut., 159, 2467-2475, 2011.

Zerva, A. and Mencuccini, M.: Short-term effects of clearfelling on soil $\mathrm{CO}_{2}, \mathrm{CH}_{4}$, and $\mathrm{N}_{2} \mathrm{O}$ fluxes in a Sitka spruce plantation, Soil Biol. Biochem., 37, 2025-2036, 2005. 